\title{
Listening for Noise in Political Thought
}

\section{BRUCE BUCHAN}

GRIFFITH UNIVERSITY

\begin{abstract}
...the most noble and profitable invention of all other, was that of SPEECH ... whereby men register their Thoughts; recall them when they are past; and also declare them one to another for mutual utility and conversation; without which, there had been amongst men, neither Common-wealth, nor Society, nor Contract, nor Peace, no more amongst Lyons, Bears, and Wolves.
\end{abstract}

Thomas Hobbes, Leviathan ${ }^{1}$

\section{-INTRODUCTION}

The association of sound and political philosophy is venerable, but usually only silently invoked in metaphor or analogy, as in Cicero's likening 'concord' among the citizens of the republic to 'harmony in song', or John of Salisbury's image of rulership as 'producing the sweetest consonance of dissonances' by 'stretching or relaxing' the variety of 'strings' in the commonwealth. ${ }^{2}$ These musical metaphors 
have at least two important implications for our understanding of how political ideas are communicated in the Western tradition of political thought. First, their antiquity implies that political ideas have frequently been communicated, even in written texts, by means of specific reference to the noise of ideas resonating in music, in speech, or in dialogue. Second, they also imply that the communication of political ideas takes place by means of purposive and meaningful 'sound' (of the orchestrated harmony of music in this analogy) rather than invasive and irritating 'noise' (to stretch the same analogy, in discordant strumming or tuneless chanting). These two implications deserve further investigation if only because political theorists have often been deaf to the ways in which the invocation of noise has been used in written texts to underscore the meaning of political ideas.

A 'widely accepted definition' of noise is that provided in Clay's Handbook of Environmental Health, which asserts that noise is any 'sound which is undesired by the recipient', typically including machinery, traffic or industrial noises. ${ }^{3}$ Noise is here associated with sonic phenomena that penetrate, that invade and pervade the spaces occupied by subjects who do not wish to hear them, and in being thus subjected, those subjects are rendered 'passive' by noise. ${ }^{4}$ This negative definition of noise as unwanted sound is challenged by those for whom noise is also a relational phenomenon linking different subjects together in shared spaces and in interactive and often purposive noise generation in speech, in music, or other sonic signs and gestures. ${ }^{5}$ While noise unites and links, it is also subject to situational variables where architectural or geographic spaces may amplify, modulate or sharpen the pitch, tone or resonance of noise to levels that may be wanted (or just tolerated) by some, unwanted by others. Indeed, the context in which hearing takes place may itself determine when the pleasurable sound of overheard music in an apartment, for example, becomes the punishing sound of interminable music employed as 'standard operating procedure' by military prison interrogators. ${ }^{6}$ The perception of noise is determined not only by such variables, but also by the mediation and inscription of meaning through language. In other words, the pounding of waves upon a shoreline is not usually heard simply as noise, but as the workings of tides, or as the pounding of surf. This linguistic inscription of meaning operates by means of the formal grammar and syntax of language, and by the variable forms of speech appropriate to particular contexts, whether in the home, classroom, public square, 
coffee house or on the floor of parliament. In this way, language mediates the individual's sonic experience, imposing, as Nancy would have it, the rationality of 'hearing' on the pure sensation and corporeality of 'listening'.7

Political ideas are typically heard in this sense. The linguistic inscription of meaning mediates between the ideas being communicated and the subjects who hear them. Ideas of liberty, justice or equality, for example, are heard not as noise, but as ideas in the purposive sound of political debate, pedagogic dialogue or the stump speeches of campaigners. In this article, however, I argue that in the communication of political ideas we can listen for a range of noises that underscore meaning. In some cases, the noise of political communication is consonant with audible speech and utterance, but even historic texts in Western thought preserve an implied acoustic dimension by invoking the noises of different kinds of speech. In listening for the sonic profile in actual speech and in textually recorded speech, sensory historians have sought to respond to the work of McLuhan and others who argued that the historic achievement of literacy resulted in the primacy of the ocular over the aural sense. This primacy resulted in meaning henceforth being conveyed more forcefully in visual means through the written rather than the spoken or performed word. ${ }^{8}$ As Mark Smith reminds us, however, the centrality of oral communication and accompanying aural and visual gestures in preliterate Europe meant that early texts were shaped by the effort to 'capture the importance of spoken words'. 9 The early history of the art of writing was 'adapted' to 'orality' by preserving the forms and echoing the noises of 'oral practice'.10 Not only was the art of writing adapted to the noise of speech, so was the art of reading. Public recitation of written texts remained standard practice in Europe well after the introduction of printing in the late fifteenth century, and silent reading (to one's self) only gradually became the norm in Europe from the thirteenth century. While it may be true, as Bruce Smith argues, that recent scholarship 'discourage[s] the study of sound', the inflection of sound and noise in written texts is regularly overlooked in the study of political thought. ${ }^{11}$

I argue that it is possible to listen for an acoustic dimension of political philosophical communication, even in written texts. The aural experience of speech is distinct from the visual (written) representation of speech in the immediacy and indetermination with which words are voiced. Written speeches often do not record 
the noise of incomprehension or dispute, but simply the texts abstracted from the noisier contexts in which they were delivered. For this reason, I will focus on five salient modes of political speech typically employed to communicate political philosophical ideas; namely, the monologue, the dialogue, the oration, the interjection and the noise of the crowd. These five modes encompass both audibly performed as well as visually or textually represented speech.12 In each of these modes, the meaning of political ideas is inflected not only in the grammar and syntax of words and sentences, but in the 'extra-linguistic' contexts in which speech is performed. Even where actual speech is not enunciated, as in a written text, meaning is still tied to the imagined contexts legitimating the varied 'intonations, speeds, pitches and resonances' of particular forms of speech used to convey meaning. ${ }^{13}$ These noises, textually invoked, could record in written words actual sounds once heard and transmitted, or they could serve as visual cues to an aural experience designed to guide, influence or persuade the reader. ${ }^{14}$ The modes discussed here may be used to communicate ideas we find to varying degrees execrable or laudable. My concern is not necessarily how we make these judgements, nor with normative evaluation between the various modes themselves, but to explore how the meaning of 'what is Said' in political speech and texts is shaped not only by 'who is Saying', but where and how they say it. ${ }^{15}$ Being attuned to the echoes of these performative noises in specific contexts-of the classroom, public square, or mass rally -is one way of contextualising different forms of political communication, and of exploring how our understanding of political ideas is informed by what we listen to, and what we don't.

Despite an apparent focus in contemporary political thought on speech or dialogue, there seems a shared presumption among contemporary scholars that political philosophy is to be studied as if it were an exercise in voiceless speech. According to Leo Strauss, for example, we should study the Western tradition of political philosophy as if we were 'listening to the conversation among the greatest minds' talking across the ages about sublime and dangerous truths, enabling us thereby to liberate ourselves from the 'vulgarity' of tawdry truisms or comforting illusions peddled amid the 'the noise, the rush, the thoughtlessness, the cheapness' of everyday public discourse. ${ }^{16}$ In contrast, and in critique of Strauss, the 'Cambridge School' of historians of political thought aim to recover the historically contingent 
meanings available to authors within essentially localised languages, or to reconstruct the specific authorial intentions behind historic texts. ${ }^{17}$ These written texts are interpreted as 'speech acts visibly performed' and 'crafted' to provide specifically non-verbal 'persuasive techniques' to replace those verbal cues that, in largely non-literate societies, established one's 'authoritative credentials to speak.'18 In what follows, I will argue that even in textual communication of political ideas, an implied acoustic dimension of imagined conversation, of staged oratory or of public tumult frames the communication of political ideas. The implied echo of these noises underscores the validity of the ideas presented by privileging certain forms of speech and types of speaker above others.

The focus on speech and the conditions and context of verbal articulation is a characteristic feature of much recent normative political philosophy. Consider both John Rawls' imagining of purely rational negotiation over principles of justice behind the fictitious 'veil of ignorance', and Jurgen Habermas' 'discourse ethics' centred on an 'ideal speech situation' encompassing mutual acceptance of shared rules and conventions of discourse. ${ }^{19}$ For both, political speech seems a theoretical possibility, a silent reflection not on the noise of actual speech but on the possibilities for more meaningful and less rowdy speech. One of the few varieties of normative political philosophy to espouse an audible sonic profile is deliberative democracy. ${ }^{20}$ Deliberative democrats entertain the possibility of genuine popular engagement in meaningful discursive interaction in diverse forums, whether legislatures, focus groups, the media, or online and virtual forms of communication.21 For some, the link between public discourse and democracy is implicit. Democracy, on this view, is not so much to be seen as to be experienced and, especially, heard. Listening for democracy means being attuned to the 'break out' of democratic engagement in our everyday lives marked by 'an increase in noise' when speech 'becomes animated and highly charged with emotion'.22 The sonic profile of democracy, perhaps more than other political discourse, may be said to be both 'logocentric' in privileging speech and 'phonocentric' in being consonant with the sounds of political contest; that is, of divisive protest or uniting chant, or simply of voices in debate. ${ }^{23}$ To designate speech as a political sound par excellence, is merely to signal a varied and variable acoustic range. I want to begin mapping that range by focusing on five performative modes typically employed in the articulation 
of political ideas. This list is not exhaustive, but the modes are united because each is based on forms or representations of political speech. This mapping begins with a form of speech characterised by the verbal, and sometimes political, ascendency of a single voice: the monologue.

\section{-1. THE MONOLOGUE}

The association of politics with speech is a venerable one in Western thought. Indeed, Dobson suggests that for Aristotle:

the capacity that distinguishes humans from other animals, and that makes the former political animals in the way in which the latter are not, is 'speech'. Speech, unlike voice, enables us to communicate judgements... ${ }^{24}$

As Dobson realises, however, establishing this foundational ontological connection does not resolve immediate practical difficulties about who speaks for whom, or about whose voice is heard before or over others. A more fundamental question relates to the differential capacity that humans have for sustained monological speech and the political opportunities to amplify it. In the modern world, it is impossible to dissociate the political consequences of monologue from the dreadful and catastrophic effects of Nazism in Germany (1933-1945). Hitler's capacity for speech, not all of it furious, lay at the base of the Nazi's rise to power. Hitler's most authoritative biographer, Ian Kershaw, notes that his speeches, regularly delivered to hundreds and often to thousands of patiently waiting listeners, would normally last 'about two hours or more' during which he would speak from skeletal notes and, in his early rise to power, display a mesmeric ability to transfix his audience. ${ }^{25}$ As one observer wrote of his oratory: 'Hitler was obsessed by his own words, a thorough fanatic with the most powerful effect on his audience; a born agitator in spite of a hoarse, sometimes broken and not infrequently croaking voice.'26 Importantly, Hitler's early speeches made use of varied strategies, including humour and sarcasm, and he displayed ability to master hecklers. ${ }^{27}$

Hitler's capacity for speech was also frequently on display in less public but equally disturbing conversational monologues. Alan Bullock has written that 'Hitler was not a man with whom anyone could have a normal conversation' either because he talked and all else had to listen, or others talked and he remained lost in his own world of thought. ${ }^{28}$ The term 'monologue' is frequently used to describe Hitler's 
conversational speeches, uttered in a peculiar daily routine focused on providing opportunities for these set piece utterances repeated ad nauseum. ${ }^{29}$ Hugh TrevorRoper has described the monological, obsessed and unrealistic table talk that Hitler engaged in toward the end of the war, all of it accompanied by a 'long succession of tea and cakes'. ${ }^{30}$ As the military situation worsened through 1942 and 1943, Hitler's 'monologues' (as one of his own secretaries described them) became more monotonous and predictable: 'On every subject we all knew in advance what he would say. In course of time these monologues bored us.'31 Significantly, over this time Hitler's public speeches gradually lost their appeal as they became ever more detached from the dire military realities. ${ }^{32}$

Hitler's unreflective and ill-informed monologues are an extreme example of the form. The ideas he conveyed were simplistic, bizarre and frightful, but they found (at least initially) a ready audience. Most importantly, Hitler's monological amplification of these ideas drowned out opposing voices and focused all attention on the sound of his authoritative voice to stun or over-awe his listeners. 33 But a monologue need not be egomaniacal, tyrannous or unreflective; nor need it be interminable. One may take as an example the Shakespearean soliloquy. The conceit of the soliloquy is that it presents in the guise of sole-authored speech, the internal dialogue of the mind where the speaker wrestles with his or her own doubts in plain hearing. The soliloquy is not framed by political power, but can be an avenue for exploring political possibilities. At times, the exploration can be shocking, as when Gloucester (the future King Richard III) puts 'the murd'rous Machiavel to school' in his open contemplation of murder and deceit as the means to power: 'Why, I can smile, and murder while I smile.' 34

But the political possibilities of soliloquy could be put to altogether more reflective ends. Hamlet's tortured reflections and indecisive meanderings of the psyche spring readily to mind, but their domain is less the realm of politics than the realm of the soul. If one may interpret soliloquy a little loosely, as an extended and single-voiced utterance that bears little relation to its ostensibly dialogic partner voices, one can find more overtly political reflections in monological voice. Few passages can have had more political resonance to Elizabethan audiences than the reflections Shakespeare placed into the mouth of an inept king, Richard II. Richard's reflections take place in the open air as battle impends, and although in dialogue 
with other characters, his speech has the air of self-reflection. ${ }^{35}$ Richard reflects on his losing cause and thinks of all the 'murder'd' kings, who, for all their puissance and potency were only men, for 'within the hollow crown, That rounds the mortal temples of a king, Keeps death his court: and there the antick sits, Scoffing his state, and grinning at his pomp ... [and] Comes at the last, with a little pin Bores through his castle-wall, and-farewell king!'36 As Ernst Kantorowicz argued, this passage is a radical restatement of the peculiarly English doctrine of the 'king's two bodies' whereby the monarch's mortal 'body natural' was said to be united with the immortal 'body politic', sundered only in death to which the prerogatives and dignitas of the body politic remains immune. ${ }^{37}$ Richard II however, radically pictures kingship as an office not eternal but inhabited by death, the office as weak and vulnerable as the man or woman who wears the crown. Unlike the maniacal monologue of the tyrant (Hitler), in which the medium of speech serves as a bludgeon to subdue dissenting voices, the soliloquy offers a uniquely flexible medium for the expression of and reflection on subversive, shocking and often complex and sophisticated political ideas. Soliloquies, however, bear little resemblance to the responsive structure of dialogue.

\section{-2. THE dialogue}

Dialogue occurs when two or more parties are in responsive communication, one with another, by voice or sign. The link between drama or theatrical performance and political ideas expressed in the medium of dialogue is intrinsic to the origins of the Western tradition of thought in Ancient Greece. As Euben describes it:

The configuration of the theatre [in Ancient Athens] encouraged a sense that all life, here exemplified by dramatic action, was public life, open to the view of all, inviting the participation of many ... In many respects tragedy was a political institution analogous to the Assembly or Council ... tragedy enabled its citizen audience to reflect on their lives with a generality denied them in their capacity as political actors. ${ }^{38}$

In his more recent Platonic Noise, Euben speculates that the television sitcom, above all The Simpsons, is the modern American version of the Athenian theatre with its potential to satirise authority. ${ }^{39}$ The noise of satirical performance exists symbiotically with the noise of political authority insofar as satire pokes fun at, 
rather than prompts rebellion against that authority. It is fitting then that Euben has the conservative Aristophanes in mind when he reflects on satire, for one of the Greek satirist's chief targets was the man Plato represented as the most strident critic of Athenian government, Socrates. Aristophanes' The Clouds was an attack on the sophists, who taught logic and philosophy for handsome fees. Aristophanes' target, Socrates, seemed an ironic choice given that Socrates was neither a sophist nor did he charge his students fees. Nonetheless, Aristophanes pilloried Socrates who is portrayed as a searcher after abstruse knowledge from the 'heavenly Clouds', who, as 'potent deities for the shiftless ... supply acumen and casuistry, verbal sleights, circumlocutions, quick repartee and knockout arguments.' 40

Aristophanes' comical Socrates sits in marked contrast to Plato's and Xenophon's Socrates, who emerges from their dialogues as a gifted teacher, a genial though sometimes stubborn interlocutor and a relentless logician. The Socratic dialogue is a variable form of political communication, never simply restricted to dry analysis it could also incorporate humour, irony, sarcasm and high-flown oratory. In the discussion of justice in Book I of The Republic, Plato uses Socrates' argumentative didacticism as a foil to both Polemarchus' conventional account of justice (as giving to each what is owed to them), and Thrasymachus' sophistic argument that justice is whatever is advantageous to the strong and powerful. In dispatching these alternatives, Plato's Socrates makes use of friendly banter and politely posed questions to lead his protagonists inexorably to own the internal contradictions of their positions. ${ }^{41}$ Thrasymachus is clearly the more formidable of Socrates' protagonists with whom he has a noisier confrontation. Thrasymachus puts his view in a forceful, seemingly relentless speech described as a 'mass of closepacked words' 'poured' into his listener's ears 'as a bathman might a flood of water'. ${ }^{2}$ Socrates again proceeded to best Thrasymachus by the same method of questioning which led his protagonist to accept (albeit less willingly than Polemarchus) that his proffered notion of justice was self-contradictory. Socrates' method of dialogical disputation, as Plato presents it, is a demonstration of how the philosophic search for truth can be pursued through conversation. 'How grand is the power of disputation', Socrates later reflects to Glaucon, because 'people fall into it unwittingly and think they are not disputing but conversing because they cannot analyse their subject into its parts.' 43 
It could be objected that The Republic is hardly a case of political philosophical noise. After all, the dialogue was written many years after Socrates' own execution, and may not have recorded actual speech. But Plato's aim was at least in part to vindicate his former master's method, which was always dialogically performed and hence publicly audible. In Plato's representation of Socratic dialogue, the validity of arguments imbibed an implicit sonic profile based on public performance. Xenophon also pictures Socrates engaging in just this kind of public performance of method involving the citizens of Athens, when he portrays him going 'around to the good carpenters' and other tradesmen, and even button-holing gentlemen to learn from them 'the finest and best ... way to make a living'. ${ }^{44}$ Xenophon's Socrates emerges as a rather idiosyncratic, single-minded but proper conversationalist. Plato's Socrates bore an obvious resemblance to Xenophon's, but they perhaps did not always sound the same. As Plato depicted him in Euthyphro, Socrates stooped to irony by feigning rapt attention in quizzing his credulous interlocutor on his rather unremarkable views on the nature of holiness. ${ }^{45}$ In The Apology, Plato's Socrates sounds more selfrighteous, defending his self-appointed task to confront his fellow citizens anywhere at anytime in order to force them to think, 'For this reason, gentlemen, far from pleading on my own behalf, as might be supposed, I am really pleading on yours, to save you' for 'god has attached me to this city to perform the office of ... everywhere, rousing, persuading, reproving every one of you. You will not easily find another like me.'46

The Socratic dialogue lies at the heart of the Western canon of political thought, both as a methodology and as a source of substantive concepts and arguments. It is by no means clear though that dialogue can be spoken of as an essentially uniform medium of political communication. It is possible to imagine that the communication of political ideas may take place in a number of dialogical forms. The set-piece Socratic dialogue may be one of these forms, characterised by its methodological quality, its explicit search for philosophical, ethical or political truth. Another possible dialogical form is the conversation, a more free-flowing and not explicitly methodological verbal exchange. All conversations are performances of some kind, nowhere more clearly demonstrated than in the theatrical conversation. In Shakespeare's Richard II, for example, the seemingly mundane conversation between two humble gardeners expresses the essence of the King's tragedy: 
Gardener: Go, bind thou up yon dangling apricocks ... and like an executioner, Cut off the heads of too-fast-growing sprays, That look too lofty in our commonwealth: All must be even in our government.

Servant: Why should we, in the compass of a pale, Keep law, and form, and due proportion, Showing, as in a model, our firm estate?...

Gardener: ... He that hath suffer'd this disorder'd spring, hath now himself met with the fall of leaf; ... Oh! What pity is it, That he had not so trimm'd and dress'd his land, as we this garden! 47

The intricacies of statecraft are here simply rendered in conversational tones by means of a familiar analogical trope. 48 The use of the state as garden analogy, voiced between two menials, invites the audience to take delight in the image of their betters as weeds in need of composting, or boughs in need of lopping. But by doing so, they are conversationally co-opted by the analogy, implicitly accepting the state as a kind of well-kept garden maintained by a divinely appointed and greenthumbed king who tends the garden-state with a benevolent but ruthless efficiency. ${ }^{49}$

Another dialogical form favoured for the communication of political ideas and the mysteries of statecraft may be called didactic dialogue. The didactic dialogical form for the instruction of princes has a long history. George Buchanan's Law of Kingship of 1579 provides an animated example of the form, where the partners fully engage and challenge one another with argument and counter-argument, humour and sarcasm. Nonetheless, Buchanan does not let his readers, or his royal patron and former pupil, Scotland's King James VI, forget that his purpose in writing the dialogue was to silence 'certain people who railed ... with unseemly cries' against the idea that sovereigns and subjects possessed 'mutual rights'. ${ }^{50}$ Buchanan asserted that his former royal pupil must willingly 'submit ... to your teachers' and shun the 'solecisms' and 'flattery' of vile courtiers. The King must listen to the Dialogue as a 'harsh and sometimes insolent critic, to steer you ... through the reefs of flattery', if need be to 'admonish you ... rebuke you and drag you back again' to the upright path.51 In Buchanan's terms, the limitations of law and the advice of the wise will make kingship into a divine model whose vocal and visual presence will reinforce the 'silent picture' of true 'honour, dignity, grandeur or majesty ... in men's minds'.52 
For all its liveliness Buchanan's Dialogue remains essentially a classroom exercise. Other conversational dialogues, less wedded to the classroom context, could experiment with a more discursive exploration of complex concepts and subtle arguments. In this latter sense, Francesco Guicciardini's Dialogue on the Government of Florence (1524) and Machiavelli's Art of War (1521) are exemplary cases. As exemplars of the latest humanist education, both were concerned with the central question of the proper engagement in and management of political life. ${ }^{53}$ In his most famous work, The Prince, Machiavelli is preoccupied with ensuring that good advice (and good advisors) be proffered to rulers. As Machiavelli presented it, the wise prince must be prepared to dissimulate; to appear virtuous, and indeed to be so when one can, but to also be prepared to 'act treacherously, ruthlessly or inhumanely' according to 'changing circumstances'.54 In order to read those changing circumstances a prince must rely on good advice by shunning flattery and 'letting it be known that being told the truth does not offend', while ensuring that licence is not given to just 'anyone' to speak so 'frankly' lest 'respect' for the prince 'soon disappear'. ${ }^{55}$ Dialogue such as this is essentially a private matter between a prince and his necessarily few trusted advisors.

In his Art of War (1521), the only one of his works published during his lifetime, the more open sound of debate is preferred to the intimate and guarded sound of princely advice. The dialogue was set in the gardens of Bernardo Rucellai (the Orti Oricellari), which served as a venue for discussion among Florence's humanist intellectuals.56 Machiavelli's interlocutors in the dialogue include leading figures from the former republican government with whom the then unemployed exsecretary of war, Machiavelli, shared lost hopes and failed ambitions. ${ }^{57}$ Machiavelli's subversive dialogue fed the fears of the English humanist, Roger Ascham, who considered the fashion for Italian politics and political thinkers would lead only to 'a busie head, a factious heart, a talkative tonge: fed with discoursing of factions' and a distaste among gentlemen for remaining 'a quiet subject to his Prince'.58

In contrast to Machiavelli's view of dialogue, Guicciardini's stance seems more equivocal.59 Guicciardini's dialogue is set some twenty-six years in the past when the Medici were first turned out of Florence's government and a republican regime was put in their place. The dialogue canvasses a variety of the advantages and disadvantages of both the Medici and republican governments. By the time of its 
authorship the Florentine diplomat Guicciardini-servant of both the republic and the restored Medici-seems concerned to blend his republicanism with measured defences of rule by the few. This equivocation results in a defence of secrecy as appropriate to matters of state, and hence of near silence as the appropriate acoustic range of government. Thus, although 'a narrow regime' in which 'one or the few' govern may be prone to errors, it was inherently well adapted to respond decisively to unexpected crises. ${ }^{60}$ At least part of the reason was that 'an open regime' was less able to 'understand the secrets and deceptions' that are the mainstay of international politics; secrets that should not be broadcast to all and sundry as if by a 'street crier'. Guicciardini castigates open and democratic government as hostile to the discretion and secrecy that 'are the means used to conduct great affairs'.

Guicciardini's defence of secrecy and the private dialogue of those 'in the know', rather than the public dialogue of open debate, is directly at odds with the modern partisans of Wikileaks who believe that government secrecy is still too pervasive and advocate online media to break down the walls of silence around statecraft. It is at least an open question whether actual dialogue, subversive or not, has been or is being replaced today with more virtual and less audible forms. Be that as it may, the representation of political dialogue in Socratic, Shakespearean, didactic or Florentine types demonstrates the wide variability of this mode of political philosophical speech. Dialogue may take place in a variety of forums, may involve from two to a much larger number of active or occasional participants, and it may be used to explore a range of ideas more or less publicly. Although the textual representations of political dialogue I have discussed here do not necessarily record actual audible speech, they each noticeably invoke aural qualities to underscore the ideas conveyed; for example, in the verbal pugilism of Plato's Socrates, or in Buchanan's insistent didacticism, or in the whispered princely advice, or even the potentially subversive banter imagined by Machiavelli. Nonetheless, the representation of speech remains a literary device in which the variable noises of audible speech are implied or, in the case of Socrates, assimilated to the interests of those (Plato, Xenophon, Aristophanes) who recorded his dialogues in their own texts. The literary formalisation of the spontaneity of dialogue points to another acoustic mode of political philosophy no less bound by its own literary conventions 
but arguably more closely aligned with the actually audible noise of political speech, the classical oration. ${ }^{61}$

\section{-3. THE ORATION}

For centuries, the oration was considered the epitome of Western rhetoric; a performative practice encompassing verbal style and bodily control designed to move an audience while also exemplifying the orator's virtue and good judgement. ${ }^{62}$ The orator's art enabled a speaker, as Early Modern treatises described it, 'to renteth all in peeces like the thunder: or else by little and little, like the flowing water creepeth by gentle meanes into the consent of ... hearers'; or to master an 'apt teaching [of] the hearers ... gettyng them to geve good eare ... [and] winnyng their favour'.63 It required careful study and diligent emulation by gentlemen who aspired to the greatness of Pericles or Cicero. ${ }^{64}$ The great eighteenth-century scholar and parliamentarian, Edmund Burke, crafted his monumental speeches in the over sixyear epic impeachment trial of Warren Hastings after the model of Cicero's Verrine Orations. ${ }^{65}$ Burke's marathon speeches on India raise an interesting question about the blurred boundary between the oration and the monologue. A dividing line between them might be that the oration is a particularly self-conscious form of speech oriented toward a particular tradition of persuasive public speaking, an orientation Burke sought to reinforce not only through performing but publishing his speeches. When the impeachment campaign against Hastings began, Burke was widely respected for the oratorical skills he had honed in Opposition. ${ }^{66} \mathrm{His}$ opening speech began on 15 February 1788 and ran for almost eight hours over four days. ${ }^{67}$

On 19 February his epic speech concluded with the now famous accusation:

I impeach Warren Hastings, Esquire, of High Crimes and Misdemeanours.

I impeach him in the name of the Commons of Great Britain in Parliament assembled, whose parliamentary trust he has betrayed.

... I impeach him in the name of the people of India, whose laws, rights and liberties he has subverted, whose properties he has destroyed, whose country he has laid waste and desolate. 68

The Hastings impeachment provided Burke with ample scope to display his rhetorical and theatrical talents to the full, regaling his listeners with hyperbole in the dramatic accusations, pathos in the lurid descriptions of lascivious corruption, 
and bloodcurdling denunciation of violence and cruelty. 69 By the time the impeachment came to its unsuccessful end in 1794, Burke was all but a broken man whose speeches were delivered to a near empty House. ${ }^{70}$ Burke's conscious emulation of Cicero's campaign to prosecute Verres, the corrupt imperial governor of Sicily, is a strong indication of the continuity of the Western tradition of rhetoric and oratory. But Cicero himself was the heir to an even longer tradition of Roman and Greek political oratory stretching at least as far back as Pericles.

Pericles' funeral oration has long been considered the original model for the Western political oration. What Pericles actually said at the funeral of the Athenian dead at the beginning of their long and bloody war with Sparta in 431-430 BCE is a mystery. The text of the oration comes from the Athenian general Thucydides' history of the Peloponnesian war. ${ }^{71}$ Thucydides reports that public processions to and orations at the gravesite of war dead was a customary Athenian accolade to their heroes. As Thucydides recounts it, Pericles' oration sounds rather more like a public lecture with statements of intent and less like a stirring example of oratory. Nonetheless, Pericles' speech successfully invoked a strong sense of an embattled Athenian identity, different and superior to other neighbouring polei in its democratic institutions and civic commitment. The Athenians' purpose, Pericles argued, must be to consecrate their dead and commit to the emulation of their courage. Three elements of the oration stand out. First is the idea of a special, unique and inherently positive collective identity. Second, there is the reality of embattlement, danger to or crisis facing that identity. Third and finally, that unique identity and desperate danger bestow a special responsibility on the living to consecrate the sacrifice of the recent dead.

Perhaps the most famous of modern orations for the consecration of the graves of war dead was US President Abraham Lincoln's 'Gettysburg Address', which has been read, in style at least, as a latter-day Periclean oration. ${ }^{72}$ Lincoln's achievement at Gettysburg may be said in part to have rested on his ability to interweave all three of Pericles' appeals into a statement of no more than 272 words, the spare eloquence and restrained elegance of which has rarely if ever been matched. Pericles' and Lincoln's orations have attracted much attention, but comparatively little has been said about them as acoustic performances. Of the sound of Pericles's oration we know little; not even Thucydides records what it sounded like or any 
response to it. What we do have, and it is little enough, is Pericles' exhortation that the glory of the heroic dead was not to be celebrated or recalled merely by silent epitaphs or mute sepulchres. Rather, 'their glory remains eternal in men's minds, always there on the right occasion to stir others to speech or to action. For famous men have the whole earth as their memorial.'73 The Periclean oration may thus be said to have had its own vocal signature; the consecration of the dead was not to be an empty and silent gesture, but an occasion for renewed speech and action.

of the sound of Lincoln's own great address we know rather more.74 Technically, the president was only there at the ceremony to consecrate the grave of the Union dead at the historic battle of Gettysburg and to make a short formal dedication, not an oration. The oration was delivered immediately before the president's address by the famed scholar and politician, Edward Everett. Everett's monumental oration was crafted to the highest contemporary standards of rhetoric, modelled carefully on the revived interest in Greek oratory. It was delivered without the aid of notes over two hours. President Lincoln spoke for about three minutes. His voice was described as being high, almost shrill, and he bore a heavy Kentucky accent that helped to convince many easterners that the he was little better than a backwoods yokel. Lincoln often seemed intent on feeding this impression and using it to his advantage. The impression of rusticity hid a much more formidable intellect and a razor sharp political cunning. Despite the common story that the speech was delivered inaudibly to an uncomprehending audience, in fact his short speech was delivered in a resonant tone and was accompanied by repeated public applause. ${ }^{75}$ His words were not triumphal, but the vision of victory infused them. While the immediacy of national crisis could hardly have been far from listeners' minds, the liberation from crisis was implicitly opened to these listeners. His words were not morbid or overshadowed by the bloody reality of sacrifice, but pointed directly at the tasks confronting the living, who must ensure that the blood shed so copiously and recently on that field will not have been wastefully lost. In doing this, he articulated what has become an incredibly powerful definition of democratic government alongside a seductive vision of a nation built on human equality.

Uniting the speeches of Pericles, Burke, Cicero and Lincoln is that all were formal examples of oratory, carefully crafted and deliberatively delivered for effect In common also with the formal Socratic dialogues, and even the monotonous 
monologue, the oration is a form of political communication that does not welcome interruption or interjection. They are all in this sense cases of disciplined political noise which to varying degrees are set in contrast to the unruly noise of the populace whose role is either to passively listen, if they have any role at all. The monologue, the dialogue and the oration are all spoken or intoned by those empowered with leave to speak. However, it is still the case that political philosophical ideas can be voiced by those without the formal authority to speak. In order to listen for these less formal, more unruly and impolite political noises, we need to turn our attention to two other performative modes of political philosophy.

\section{-4. THE INTERJECTION}

The interjection is the forceful, spontaneous and acerbic interruption of an existing discourse. An interjection may certainly be loud, or at least noisy, and inserted into political debate and in a public forum, an interjection may certainly have a political character-but can an interjection really convey an idea? The usual presumption of political theorists is that the communication of political ideas is the preserve of political philosophy, understood as a self-conscious reflection on political ideas or arguments by scholars who employ conceptual tools derived from the work of other scholars. Political philosophy in this sense is a highly restricted activity, restricted in the sense that only the utterances of ordained members of the cannon (Socrates, Plato, Aristotle, Machiavelli and so on) count as genuine political philosophy. But this view pays scant regard to the dissemination and use of political ideas in a variety of contexts by less exalted persons. Thus Socrates' engagement with the craftsmen around the Agora in discussions of goodness may be taken as an example of political philosophising, as indeed was the engagement with ideas of liberty and rights by the ordinary soldiers of the parliamentary army in their debates at Putney in 1649-50.

If these and other instances can be considered examples of political philosophising, when can an interjection be so considered? Here it may be objected that an interjection is by its nature too abrupt, unreflective, discordant and brief to be considered as an example of extended or critical reflection on political ideas or argument. Something of this objection lies behind the presupposition in Western thought that interruptions of dialogue and discourse, by means of protests or the 
shouting of slogans, are by their nature unmeditative and unhelpful in advancing reasoned political argument. As Iris Marion Young argued, the interruption of political dialogue by 'activists' is often perceived as the very antithesis of democratic deliberation:

Typically, the activist eschews deliberation, especially deliberation with persons wielding political or economic power and official representatives of institutions he believes perpetuate injustice or harm. He finds laughable the suggestion that he and his comrades should sit down with those whom he criticizes ... Thus, the activist takes other action that he finds more effective in conveying his criticism and furthering the objectives he believes right: picketing, leafleting, guerilla theater, large and loud street demonstrations, sit-ins, and other forms of direct action, such as boycotts. Often activists make public noise outside when deliberation is supposedly taking place on the inside. ${ }^{76}$

There is no doubt the rude interruption or noisy interjection is often brusque, intrusive and confronting. But to consign all such interjections to a political nether world beyond the pale of informed and enlightened discourse (and philosophising) is to risk a deadening of political discourse. The interjection by means of protest may take a variety of forms including noisy street marches, the performance of song, participation in anthems, or the staging of street theatre. In each of these ways, noise is a disruption of and a challenge to the 'official scripting' of 'public space' and the regulation of appropriate noise within it. 77 The interjection thus dramatically signals a different, discordant engagement in public noise.

If we restrict attention only to solo-voiced, spoken interjections, it is certainly the case that they may serve to bring a discourse to a dead end, as did Oliver Cromwell's spectacular interjection in proceedings on 20 April 1653 to dismiss the so-called 'Rump' Parliament because of its rampant and scandalous moral corruption. ${ }^{78}$ A more philosophically significant, and less autocratic but still just as shocking interjection is provided by Nietzsche's parable of the Madman who interrupted the complacent chatter among citizens in the market place. Strictly speaking this story, unlike Cromwell's interjection in 1653, is not an actual example of acoustic politics. But the ramifications of the interjection, and its political significance, were underscored by Nietzsche's giving this episode a distinctive 
acoustic profile which is crucial to its interpretation. The Madman rudely accosts the citizens milling in the market place amid the comforting hubbub of polite and vacuous chatter or commercial dealings. The Madman's is a voice that the herd-like citizens do not wish to hear, but having heard it they are likely not to comprehend. 'I seek God!' the Madman proclaims, only to be met with laughter, scorn and taunting yells from the crowd. The only reply he receives is his own:

We have killed him-you and I. All of us are his murderers ... God is dead. God remains dead. And we have killed him. How shall we comfort ourselves, the murderers of all murderers? What was holiest and mightiest of all that the world has yet owned bled to death under our knives: who will wipe this blood off us? What water is there for us to clean ourselves? What festivals of atonement, what sacred games shall we have to invent? Is not he greatness of this deed too great for us? Must we ourselves not become gods simply to appear worthy of it? ${ }^{79}$

Nietzsche records that at the close of this startling interjection the Madman and the crowd 'fell silent' and 'they stared at him in astonishment'. This silence stands for the incomprehension of the crowd, but only the Madman knows the import of that silence. He declares finally that he has come too soon, for the awesome responsibility of the deed of divine murder 'has not yet reached the ears of men'. The Madman's is an interjection not simply in the stream of dialogue, but in the stream of modern collective consciousness. It is meant to arrest the attention of listeners and readers, and to strip away the comforting illusions of everyday life. God and the divine have been reduced to a platitude, an empty observance. Awakening to the discordant sound of this accusation requires the Madman's hearers to shoulder the burden of the awesome responsibility for killing god. Now ethics must be founded anew upon the 'will to power' requiring that humanity does not merely mask the divine absence by empty invented rituals, but to become the divine and thereby fulfil the promise of the death of god. Significantly, it is the discordant force of the interjection, and the deafening silence of the crowd that pinpoints Nietzsche's lesson in this parable. The interjection can dramatically highlight a political idea, or point to the need for further argument, but it cannot in and of itself supply the need to which it points. For this to happen an interjection must be welcomed and engaged with, the voice from the wilderness must be 
answered for dialogue to ensue. But what if the interjection is not a voice from the wilderness, but a collective roar?

-5. THE NOISY CROWD.

As a performative mode of politics, few could doubt that crowds are a productive source of noise, whether of unbridled riot, ordered protest, parliamentary confrontation or the orchestrated approbation of a tyrant. I focus here on whether one type of noisy crowd-the people or masses-can be a productive source of political philosophical ideas. Early Modern republicans such as Machiavelli, who looked back nostalgically to Rome before the Caesars, celebrated the unruly noise of public argument and tumult as the necessary means of political decision. In the terms of the old adage, vox populi vox dei, the voice of the people was the voice of god, or at least possessed a kind of collective wisdom less prone to the error of a prince's private and often selfish judgement. ${ }^{80}$ Republican nostalgia was given short shrift by those, such as Hobbes and Locke, who favoured a more sanitised, and typically more silent public. For them, the noise of the multitude is a sound that must be screened from important political deliberations. In Thomas Hobbes' influential argument for awesome sovereignty backed by force and fear as the only sure source of security, the institution of sovereignty was tied to a covenant by which the individual voices of the multitude were transformed into the authoritative single voice of the sovereign. ${ }^{81}$ This multitudinous consent or 'real unitie' was imagined as a mutual contract or covenant made between subjects, 'as if every man should say to every man, I Authorise and give up my Right of Governing my selfe, to this man, or to this Assembly of men, on this condition, that thou give up thy Right to him, and Authorise all his Actions in like manner'. ${ }^{82}$ This highly regimented collectively or mutually intoned contract has been a remarkably appealing model in Western thought for the legitimation of sovereign authority, but it bore only a tenuous resemblance to the unruly collective noise of the crowd. John Locke gave even less credence to the sound of the collective by arguing that (albeit limited) sovereign authority could be legitimated by an unspoken contract to which a silent tacit consent was given by 'living quietly' under the laws of any existing government. 83 
At the other extreme from Hobbes' and Locke's distaste for the noise of the crowd, lies the argument of the anarchist prince, Peter Kropotkin, whose The Great French Revolution (1909) was written specifically to correct what he saw as the deliberate writing out of the crowd, especially the Parisian working class, as an active participant in the events of 1789 to 1793. In his view, the radical promise of the revolution relied on the assertiveness and acuity of the restive and noisy crowd. In this vein he wrote of the early gatherings of the three estates 'under the watchful eyes and menaces' of the crowd who 'filled the galleries', who 'insulted and hustled' and 'hissed' their perceived enemies among the nobility, clergy and state officials. ${ }^{84}$ The crowd, which he described as the 'collective mind of the people of Paris', was much more than an angry mob. 85 It was, in his view, a thinking, talkative and above all active entity, regularly meeting in the Palais-Royale or elsewhere to debate ideas, hear the news, and 'to know and to understand one another'. 86

From a political philosophical point of view, Kropotkin's celebration of the unruly crowd bears more than a passing resemblance to Machiavelli's argument that the liberty and strength of a free people depends on noise and tumult in the republic. According to Machiavelli's reading of Livy, the liberty and strength of the Roman Republic derived from the dynamic tension between the plebs and patricians which frequently broke out in public 'noise and clamour':

Look how people used to assemble and clamour against the senate, and how the senate decried the people, how men ran helter-skelter about the streets, how the shops were closed and how the plebs en masse would troop out of Rome...87

In answer to the charge that the common people were but a mindless herd, Machiavelli asserted that although 'the populace may be ignorant, it is capable of grasping the truth and readily yields when a man, worthy of confidence, lays the truth before it'. 88 This is hardly a ringing endorsement of the acoustics of collective political thought and action, but neither is it a complete dismissal. As a forum for the exploration of political ideas and argument, the incensed, agitated and tumultuous crowd has obvious limitations. Nonetheless, it would be unwarranted to assume that the noise of such crowds cannot be informed by and reflect back on political ideas and argument. In their different ways, Machiavelli and Kropotkin were both distinctive in giving serious consideration to this view, and in doing this they 
challenged the common assumption in the Western tradition that unruly crowd noise has no role in the history of political philosophy.

\section{-CONCLUSION: THE WHITE NOISE OF DEMOCRACY}

In the Western tradition of political thought, noise is often represented as that which must be excluded if real communication is to take place. Noise is the almost incomprehensible utterance of the 'outsider' or the 'noisy crowd' regularly excluded by both 'nation-states that privilege certain speakers united by a common language' and by 'academic-scholarly circles which reinforce disciplining and normalizing standards'89 By listening for the sonic cues in the communication of political ideas we can better appreciate how these standards operate by privileging particular speakers (such as the conspiratorial voice of Guicciardini or the tyrannous voice of Hitler), or restricting meaningful communication to particular settings (such as Buchanan's royal classroom, or Xenophon's polite Socratic dialogue, or Plato's pugnaciously didactic Socratic dialogue). In these ways, some political noises are simply screened out from and opposed to genuine political philosophical reflection and communication. In this vein, Machiavelli and Buchanan warned of the dangers of flattering talk, Guicciardini recommended the secretive and almost silent passage of the corridors of power, Young pointed to the limitations of noisy interjection, while Strauss lauded our engagement in the silent conversation between the great minds of the Western canon. In each of these ways, the communication of political philosophical ideas is framed by an implicit sonic register, even when invoked in written texts, that shapes interpretive possibilities by privileging, dismissing, recommending or condemning particular contexts for and kinds of speech.

At one level, political speech is meant to be heard, as Nancy suggested, in the sense that words, grammar and syntax convey ideas and arguments that are meant to demonstrate, convince or persuade. But if the medium of political speech is at least as important as the message itself, the sonic register of political communication must also be listened to in order to account for the ways that the noise of speech, or the textual invocation or imagination of speech, shapes the message. ${ }^{90}$ In each of the performative modes outlined in this essay, the noise of speech, even imagined speech, relates speaker and audience in the constitution of a shared space for communication. The role of either participant in these performative relationships 
may be more or less passive or active, and only in some are audiences actively invited to participate as speakers, to question what is said, to argue the point, or even to loudly push political speech into new arenas beyond the sanitising control of privileged speakers. In each mode, political speech imbibes a sonic register that, to return to the qualities of noise, emanates within and pervades shared spaces with sounds that may or may not be wanted by those who hear them, but unquestionably links speakers and hearers (and listeners) together.

In contemporary democratic politics, abuzz with the incessant noise of the 24hour news cycle, the constant quest for the 10-second sound bite and the drone of media commentary, this relationship has taken on a different quality. For some, this new quality relates to the way that professional political candidates, political parties and media advisers have 'fostered and channelled' political dialogue with the voting public. ${ }^{91}$ Unlike the performative modes discussed previously, this is a heavily mediated form of political communication based on the concession that actual dialogue and conversation between citizens would be 'too tenuous in practice or far too demanding a requirement' for most citizens. The result is a form of political speech, often highly crafted and pre-tested down to the choice of words and phrases, aimed at manipulating public perceptions, sometimes by means of 'dog whistle' allusions that resonate among the public almost under the radar. ${ }^{92}$ In other words, this is political speech designed to enable us to hear a specific message, or to hear what is said without perhaps listening to the sonic register itself. 93

Whether this represents a new form of political speech or just an elaboration of established modes, such as classical oratory in a new electronic media setting, its sonic register is different. The five modes explored in this essay each imbibed a faceto-face quality, which though highly crafted or deliberately staged were essentially unmediated by others. Socrates' speech, it is true, was mediated by the intentions of the writer (such as Plato) who recorded, embellished or invented it, but even here the text was suffused by invocations of noise, which, like the noise of public speaking, invited an active listening. The five acoustic modes are also episodic in the sense that they relate to specific contexts for oratory, for monologue or dialogue, for secret conversation or sudden interjection. Contemporary democratic political speech by contrast is now characterised by a constancy of talk that is both heavily mediated (by spin doctors, focus groups and the media), but also intimate in being 
brought directly to us, and even chosen by us through digital social media technologies, with an almost endless immediacy. Contemporary democratic political speech encompasses a range of sounds and noise-of media grabs, sound bytes, vox pops, pod and vodcasts - that blend together to create political white noise, an almost constant vocal buzz and electronic static hiss through which political ideas are now communicated almost instantaneously, on demand and across sometimes vast geographic spaces. ${ }^{94}$ Political white noise is not an entirely meaningless hum or roar, nor does its unerring volume make genuine political communication, critical reflection, engagement, discussion or debate impossible. On the contrary, there is more perhaps to be feared from the 'pursuit of silence through policy' than the amplification of political white noise. ${ }^{95}$ Political white noise can at least be listened to in ways reminiscent of listening to the five acoustic modes discussed here. By so listening, audiences did not only hear what was said in these contexts, but also listened for the ways in which the noise of oratory, debate or dialogue shaped the message by privileging certain speakers, certain arguments or certain ideas over others. Listening to contemporary political white noise similarly enables us to practice what Judith Butler called 'hearing beyond what we are able to hear' in order to discern among the range of noise the quieter tones of the 'usual give-and-take of everyday political conversations'.96 Listening for the noise of political speech, whether formal rhetoric, formulaic argument or even political fantasy or storytelling, is an activity of a sensate citizenry alive to the multiple ways in which politics registers not only through intellectual reasoning, but through our senses and our willingness to listen for the varied and variable sounds of political speech across the sonic spectrum.

Bruce Buchan is a political theorist with an interest in the historical uses and transformations of political concepts. He is currently working on a project on the history of discourse on asymmetric warfare in the eighteenth century, supported by an ARC Future Fellowship. This project builds on research in his previous book, The Empire of Political Thought: Indigenous Australians and the Language of Colonial Government (2008). In addition, Bruce is completing a jointly authored monograph 
on the conceptual history of corruption and in 2011 co-edited an issue of Cultural Studies Review titled 'The Death Scene'. With Peter Denney, David Ellison, John Barrell and Harriet Guest, he has recently been awarded an ARC collaborative grant for a project titled 'Policing Noise: The Sounds of Civility in British Discourse, c. 1700-1850'.

\section{-NOTES}

Research for this paper was supported by an Australian Research Council Future Fellowship hosted by the Centre for Excellence in Policing and Security at Griffith University. I would like to thank the participants at the 'on Noise' symposium, Griffith University 2011, and the referees for their comments.

1 Thomas Hobbes, Leviathan, ed. R. Tuck, Cambridge, Cambridge University Press, 1996 [1651], Part I, ch. iv, p. 24.

2 Cicero, On the Commonwealth and On the Laws, ed. J.E.G. Zetzel, Cambridge University Press, Cambridge, 1999, Book II, pp. 56-7; John of Salisbury, Policraticus: Of the Frivolities of Courtiers and the Footprints of Philosophers, Cambridge University Press, Cambridge, 1990 [1154-59], Book IV, p. 51.

3 J.F. Leech and M. Squires, 'Noise' in Clay's Handbook of Environmental Health, ed. W.H. Bassett, Routledge, London, 1999, no pagination.

${ }^{4}$ George Prochnik, In Pursuit of Silence: Listening for Meaning in a World of Noise, Anchor, New York, 2010, pp. 106-7; B.R. Smith, 'Mouthpieces: Native American Voices in Thomas Harriot's True and Brief Report of ... Virginia, Gaspar Pérez de Villagrá's Historia de la Nuevo México, and John Smith's General History of Virginia', New Literary History, vol. 32, no. 3, 2001, p. 505.

5 Brandon LaBelle, Acoustic Territories/ Sound Culture and Everyday Life, Continuum, London, 2010, p. 62.

${ }^{6}$ Suzanne Cusick, "'You are in a place that is out of the world...": Music in the Detention Camps of the “Global War on Terror"', Journal of the Society for American Music, vol. 2, no. 1, 2008, p. 14.

${ }^{7}$ Jean-Luc Nancy, Listening, trans. C. Mandell, Fordham University Press, New York, 2007, pp. 5-7, 32-

3; Jean-Luc Nancy, Corpus, trans. R.A. Rand, Fordham University Press, New York, 2008, p. 115.

8 This argument is reviewed in M.M. Smith, 'Echoes in Print: Method and Causation in Aural History', The Journal of the Historical Society, vol. II, no. 3-4, 2002, p. 320.

${ }_{9}^{9}$ M.M. Smith, Sensing the Past: Seeing, Hearing, Smelling, Tasting, and Touching History, University of California Press, Berkeley, 2007, p. 43.

10 S.R. Fischer, A History of Reading, Reaktion Books, London, 2003, p. 142. The following material on reading aloud was drawn from pp. 192-3. 
11 B.R. Smith, 'How Sound is Sound History? A Response to Mark Smith', The Journal of the Historical Society, vol. II, no. 3-4, 2002, p. 310.

12 In this sense, I seek to uncover how the meaning conveyed in written speech is often underwritten by the invocation of a sonic profile, in being represented as whispered, loudly intoned or vigorously disputed by other voices. If written speech is not necessarily always imitative of actual, audibly performed speech, nor need it necessarily and always be seen as a 'falsification' of actual speech. B.R. Smith, 'Mouthpieces', p. 515.

13 A. Kanngieser, 'A Sonic Geography of Voice: Towards an Affective Politics', Progress in Human Geography, vol. 36, no. 3, 2012, p. 340; M. Dolar, A Voice and Nothing More, MIT Press, Cambridge (MA), 2006, p. 21; B. Smith, 'Producing Sense, Consuming Sense, Making Sense: Perils and Prospects for Sensory History', Journal of Social History, vol. 40, no. 4, 2007, p. 849.

14 Bruce and Mark Smith reflect on how Early Modern Europeans sought to 'record' noise or to incorporate visual 'cues' to noise in texts by means of metaphor and simile for example. See, B. Smith, 'How Sound is Sound History?', p. 311; M. Smith, 'Echoes in Print', p. 319.

15 A. Cavarero, For More Than One Voice, trans. P. Kottman, Stanford University Press, Stanford, 2005, p. 29.

16 Leo Strauss, Liberalism Ancient and Modern, University of Chicago Press, Chicago, 1995 [1968], pp. 78.

17 John G.A. Pocock, Virtue, Commerce and History, Cambridge University Press, Cambridge, 1985, p. 4; Quentin Skinner, 'Meaning and Understanding in the History of Ideas' in Meaning and Context: Quentin Skinner and his Critics, ed. J. Tully, Polity Press, Cambridge, 1988.

18 J.G.A. Pocock, 'Quentin Skinner: The History of Politics and the Politics of History', Common Knowledge, vol. 10, no. 3, 2004, p. 542; Conal Condren, 'The Problem of Audience, Office and the Language of Political Action in Lawson's Politica and Hobbes's Leviathan', Zeitschrift für Historische Forschung, no. 26, 2001, p. 288.

19 John Rawls, A Theory of Justice, Oxford University Press, Oxford, 1971, pp. 48-51, 136-42. J. Habermas, Moral Consciousness and Communicative Action, MIT Press, Cambridge, Mass, 1990, pp. 1307; J. Habermas, Between Facts and Norms: Contributions to a Discourse Theory of Law and Democracy, MIT Press, Cambridge, Mass, 1998, p. 458.

${ }^{20}$ A. Gutmann and D. Thompson, Democracy and Disagreement, Belknap Press of the Harvard University Press, Cambridge, Mass, 1996, pp. 353-6

${ }^{21}$ See for example, B. Ackerman and J.S. Fishkin, 'Deliberation Day', Journal of Political Philosophy, vol. 10, no. 2, 2002, pp. 129, 134-5, 147; J.S. Dryzek, 'Deliberative Democracy in Divided Societies: Alternatives to Agonism and Analgesia', Political Theory, vol. 33, no. 2, 2005, pp. 223-4; D.M. Ryfe, 'Does Deliberative Democracy Work?', Annual Review of Political Science, vol. 8, 2005, pp. 58-63. 
22 R. Blaug, 'New Theories of Discursive Democracy: A User's Guide', Philosophy and Social Criticism, vol. 22, no. 1, 1996, p. 61.

23 Dolar, p. 52; E. Markovits, 'The Trouble With Being Earnest: Deliberative Democracy and the Sincerity Norm', The Journal of Political Philosophy, vol. 14, no. 3, 2006, pp. 249-53.

24 A. Dobson, 'Democracy and Nature: Speaking and Listening', Political Studies, vol. 58, 2010, p. 753.

25 Ian Kershaw, Hitler 1889-1936: Hubris, Penguin, London, 1998, p. 149.

26 Quoted in Kershaw, Hitler 1889-1936, p. 357.

27 Alan Bullock, Hitler and Stalin: Parallel Lives, Harper Collins, London, 1991, pp. 79-81.

28 Bullock, p. 424.

${ }^{29}$ Ian Kershaw, Hitler 1936-1945: Nemesis, Penguin, London, 2000, p. 198.

30 Hitler's Table-Talk 1941-1944. His Private Conversations, trans. N. Cameron and R.H. Stevens, Enigma Books, New York, 1953/2000, p. xvi.

${ }^{31}$ Hitler's Table-Talk, p. xix. Kershaw, Hitler: 1936-1944, pp. 396-7 and 777.

32 Kershaw, Hitler: 1936-1944, pp. 540-1 and 555-6.

33 Prochnik, pp. 69-70, 85-6.

34 Third Part of King Henry VI, Act II, scene ii. Gloucester voices his determination to 'prove a villain' in The Life and Death of King Richard III, Act I, scene i.

35 John J. Norwich, Shakespeare's Kings: The Great Plays and the History of England in the Middle Ages: 1337-1485, Scribner, New York, 1999, pp. 125, 217.

36 The Life and Death of King Richard II, Act III, scene ii.

37 Ernst H. Kantorowicz, The King's Two Bodies. A Study in Medieval Political Theology, Princeton University Press, Princeton, 1957/1997, pp. 30-1.

38 J.P. Euben, Corrupting Youth: Political Education, Democratic Culture, and Political Theory, Princeton University Press, Princeton, 1997, p. 73.

39 J.P. Euben, Platonic Noise, Princeton University Press, Princeton, 2003, p. 70.

40 Aristophanes, 'The Clouds' in The Complete Plays of Aristophanes, ed. M. Hadas, Bantam, New York, 1962, p. 110.

41 Plato, The Republic, trans. G.M.A. Grube, Pan, London, 1974, Book I, 331e-5e.

42 Plato, Republic, Book I, 344d.

43 Plato, Republic, Book V, 454.

44 Xenophon, Oeconomicus, trans. C. Lord in L. Strauss, Xenophon's Socratic Discourse. An Interpretation of the Oeconomicus, Cornell University Press, Ithaca, 1970, pp. 27-8. 
45 Plato, Euthyphro in The Last Days of Socrates, trans. H. Tredennick and H. Tarrant, Penguin, London, 1954, pp. 9-30.

46 Plato, The Apology in The Last Days of Socrates, 30d-31a, p. 57.

47 Richard II, Act III, scene iv.

48 Hence Hamlet's bleak appraisal of Denmark under his suspected uncle Claudius' rule as 'an unweeded garden, That grows to seed...' (Hamlet Prince of Denmark, Act I, scene ii).

49 R.S. Miola, Shakespeare's Reading, Oxford University Press, Oxford, 2000, pp. 48-9.

50 George Buchanan, A Dialogue on the Law of Kingship Among the Scots [1579], trans. and ed. M.S. Smith and R.A. Mason, Saltire Society, Edinburgh, 2006, p. 37.

${ }^{51}$ Buchanan, Dialogue, pp. 37-8.

52 Buchanan, Dialogue, p. 87.

53 Hans Baron, In Search of Florentine Civic Humanism; Essays on the Transition From Medieval to Modern Thought, Vol. I, Princeton University Press, Princeton, 1988, pp. 137-43.

54 N. Machiavelli, The Prince [1513/1532], ed. Q. Skinner and R. Price, Cambridge University Press, Cambridge, 1988, p. 62.

55 Machiavelli, The Prince, p. 81. In his later Discourses, Machiavelli also warned of the danger that advisors remain 'silent and not... express their views' till it is too late. N. Machiavelli, The Discourses on the First Ten Books of Livy [1519/1531], trans. L.J. Walker, ed. B. Crick, Penguin, London, 1970, Book III, ch. $x x x v$, p. 502.

56 N. Machiavelli, The Art of War [1521], trans. E. Farneworth, Da Capo, New York, 1965, Book I, p. 9. According to Viroli, from 1517 the Orti became the setting for regular gatherings of like-minded intellectuals, estranged from the restored Medici regime. Maurizio Viroli, Niccolò's Smile: A Biography of Machiavelli, Farrar, Straus and Giroux, New York, 2000, pp. 185, 186, 220-1.

57 See for instance, Machiavelli, Art of War, Book I, pp. 40-2; Book II, pp. 64-71; Book III, pp. 83-7.

58 Roger Ascham, The Scholemaster, or Plaine and Perfite way of Teachyng Children, London, 1570, p. 30.

${ }^{59}$ F. Chabod, Machiavelli and the Renaissance, trans. D. Moore, Bowes and Bowes, London, 1958, pp. 109-15.

60 F. Guicciardini, A Dialogue on the Government of Florence, ed. A. Brown, Cambridge University Press, Cambridge, 1994, Book I, p. 60. The quotes are from page 61.

61 On debate over oratorical style see M. Peltonen, 'Rhetoric and Citizenship in the Monarchical Republic of Queen Elizabeth I' in The Monarchical Republic of Early Modern England, ed. J.F. McDiarmid, Ashgate, Aldershot, 2007, pp. 114-17.

62 J. Connolly, The State of Speech: Rhetoric and Political Thought in Ancient Rome, Princeton University Press, Princeton, 2007, pp. 134-5. 
63 Henry Peacham, The Garden of Eloquence, Conteining the Most Excellent Ornaments, Exornations, Lightes, Flowers, and Formes of Speech, H. Jackson, London, 1593, p. 121; Thomas Wilson, The Arte of Rhetorique, for the use of all Suche as are Studious of Eloquence, John Kingsley, London, 1553, fol. 55. 64 In the Western tradition, the art of rhetoric involved the studied crafting of public utterance, in which the aim (crudely put) was to persuade audiences by appeals to 'ethos' (or the character of the speaker), 'pathos' (or emotive language), and 'logos' (or the construction of rational argument). Cicero's four speeches on the Cataline conspiracy are among the most well known examples of all three rhetorical appeals. See, Cicero, 'Against Lucius Sergius Catalina' in Cicero: Selected Political Speeches, trans. M. Grant, Penguin, Harmondsworth, 1969, Speech I, p. 82-3; Speech III, pp. 112-16; Speech II, pp. 106-8; Speech IV, p. 137. On rhetoric in the Western tradition see the essays in C.S. Lipson and R. A. Binkley (eds), Rhetoric Before and Beyond the Greeks, State University of New York Press, New York, 2004.

65 E.D. Samet, 'A Prosecutor and a Gentleman: Edmund Burke's Idiom of Impeachment', English Literary History (ELH), vol. 68, 2001, p. 397. Also see, Cicero, The Verrine Orations, trans. L.H.G. Greenwood, Vol. I and II, Harvard University Press, Cambridge, 1928 and 1935. Hastings was the former governor general of the British East India Company government in Bengal.

66 I. Harris, 'Publishing Parliamentary Oratory: The Case of Edmund Burke', Parliamentary History, vol. 26, no. 1, 2007, pp. 112-30; and P. Bullard, Edmund Burke and the Art of Rhetoric, Cambridge University Press, Cambridge, 2011, pp. 5-9.

${ }^{67}$ E. Burke, 'Speech on Opening of Impeachment', in The Writings and Speeches of Edmund Burke, Volume VI: India: The Launching of the Hastings Impeachment 1786-1788, ed. P.J. Marshall, Oxford University Press, Oxford, 1991, pp. 266-7.

68 E. Burke, 'Speech on Opening', in The Writings and Speeches of Edmund Burke, Vol. VI, p. 459.

Compare Burke here to Cicero's closing accusations against Verres. Cicero, 'The Second Speech Against Gaius Verres, Book V', The Verrine Orations, Volume II, v. 72, §184-188, pp. 671-7.

${ }^{69}$ B. Bolton, 'Imperial Sensibilities, Colonial Ambivalence: Edmund Burke and Frances Burney', ELH, vol. 72, 2005, pp. 872-7.

70 E. Burke, 'Speech in Reply, 28, 30 May, 3, 5, 7, 11, 12, 14, 16 June 1794', in The Writings and Speeches of Edmund Burke, Volume VII: India: The Hastings Trial 1789-1794, 2000, pp. 231-694.

${ }^{71}$ Pericles' oration can be found in Thucydides, History of The Peloponnesian War, trans. R. Warner, Penguin, Harmondsworth, 1954, pp. 143-51.

72 G. Wills, Lincoln at Gettysburg: The Words that Remade America, Simon and Schuster, New York, 1992, p. 52.

73 Thucydides, History, p. 149.

${ }^{74}$ Wills, Lincoln, pp. 19-40. 
75 'The Heroes of July; A Solemn and Imposing Event. Dedication of the National Cemetery at Gettysburgh...', New York Times, 20 November 1863,

<http.www.//nytimes.com/1863/11/20/news/heroes-july-solemn-imposing-event-dedicationnational-cemetery-gettysburgh.html> (accessed 21 May 2012).

76 I.M. Young, 'Activist Challenges to Deliberative Democracy', Political Theory, vol. 29, no. 5, 2001, p. 673.

77 LaBelle, p. 115.

78 T. Salmon, The Chronological Historian: Containing a Regular Account of all Material Transactions and Occurrences, Ecclesiastical, Civil, and Military..., London, 1733, p. 119.

79 F. Nietzsche, The Gay Science [1882/1887], ed. Bernard Williams, Cambridge University Press, Cambridge, 2001, §125, pp. 119-20.

80 Machiavelli, Discourses, I, ch. lviii, pp. 252-7.

${ }^{81}$ Hobbes, Leviathan, Part I, ch. xvi, p. 114.

82 Hobbes, Leviathan, Part II, ch. xviii, p. 120.

83 John Locke, Two Treatises of Government [1690], ed. P. Laslett, Cambridge University Press,

Cambridge, 1988, §119-22, pp. 347-9. While Locke thought a 'quiet' submission to tyranny wrong, and defended a right to rebellion, he also heavily qualified that right. Rebellion was in fact a last and unlikely resort. No 'busie head, or turbulent spirit' could sway others into rebellion unless government abuses had become manifestly excessive. §228-30, pp. 416-17.

84 Peter Kropotkin, The Great French Revolution 1789-1793 [1909], Cosimo, New York, 2009, pp. 26, 56.

85 Ibid., p. 155.

86 Ibid., p. 61.

87 Machiavelli, Discourses, I, ch. iv, pp. 113-14.

88 Ibid., ch. iv, p. 115.

${ }^{89}$ C. Romany, 'Interrupting the Dinner Table Conversation: Critical Perspectives, Identity Politics and Deliberative Democracy', Proceedings of the Annual Meeting of the American Society of International Law, vol. 93, 1999, p. 190.

90 M. MacDonald, 'Empire and Communication: The Media Wars of Marshall McLuhan', Media, Culture and Society, vol. 28, 2006, p. 515. I leave aside here McLuhan's assertion that 'the medium is the message', and his effort to chart how media are not simply used by us, but shape our very perception. M. McLuhan, Essential McLuhan, Anansi Press, Toronto, 1995, pp. 239-46.

91 A.F. Simon, The Winning Message: Candidate Behaviour, Campaign Discourse, and Democracy, Cambridge University Press, Cambridge, 2002, pp. 152, 156. 
92 R.E. Goodin and M. Saward, 'Dog Whistles and Democratic Mandates', The Political Quarterly, vol. 76, no. 4, 2005, pp. 471-6; Ackerman and Fishkin, 'Deliberation Day', p. 132.

93 As Judith Butler has suggested, the act of speaking is rarely reducible only to what a speaker 'says'. Rather, it encompasses speech as well as the multiple signs, gestures and utterances that often convey meaning beyond the spoken word. J. Butler, Excitable Speech: A Politics of the Performative, Routledge, New York, 1997, p. 10.

94 L.A. Staeheli, 'Political Geography: Democracy and the Disorderly Public', Progress in Human Geography, vol. 34, no. 1, 2010, p. 68.

95 Prochnik, p. 215.

96 J. Butler, 'Explanation and Exoneration, or What we can Hear', Social Text, vol. 29, no. 3, 2002, p. 188; H.K. Gerken and D.B. Rand, 'Creating Better Heuristics for the Presidential Primary: The Citizen Assembly', Political Science Quarterly, vol. 125, no. 2, 2010, p. 241. 